\title{
LO QUE NO FIGURA EN "LA EXPEDICIÓN”: EL MOTÍN DEL TERCIO VIEJO DE BERNARDO ALDANA EN HUNGRÍA, 1553 ${ }^{1}$
}

\author{
Zoltán Korpás \\ zoltan.korpas1@gmail.com
}

\section{RESUMEN}

La expedición de Bernardo de Aldana a Hungría y los hechos del Tercio Viejo de Nápoles por aquel país lejano entre 1548 y 1552 es una fuente bien conocida y públicada en diversas lenguas. Mientras tanto apenas tenemos constancia sobre el fin del primer Tercio Viejo de Nápoles y su Maestre de Campo Bernardo de Aldana. El artículo presenta un episodio especial del aquel tercio: el motín de 400 militares españoles, el desenlace de la desobediencia y la disolución del primer Tercio Viejo de Nápoles por aquellas tierras en 1553. A la vez presenta detalladamente los últimos años de la carrera de Bernardo de Aldana, incluyendo su liberación, nuevos cargos militares por Italia y su muerte en 1560 en la batalla de Gelves. Un aspecto más es la presentación de los paralelismos históricos entre los dos frentes lejanos de la lucha contra el Imperio Otomano tanto por el Mediterráneo como por Hungría.

PALABRAS CLAVE: Tercios Viejos, Historia de Hungría, Guerras contra los otomanos, Revueltas militares, Tercio de Nápoles

\section{WHAT IS NOT INCLUDED IN "LA EXPEDICIÓN": THE REVOLT OF THE SPANISH TERCIO OF BERNARDO DE ALDANA IN HUNGARY, 1553}

\begin{abstract}
The Expedición de Bernardo de Aldana a Hungria is a well-known source published in different languages, relating to the activity of the Old Tercio of Naples in Hungary (1548-1552). Nevertheless, we have far more less information about the fate of the first Old Tercio of Naples and its Maestre de Campo, Bernardo de Aldana, after 1552. This study presents a unique episode of the military history of that Tercio: the revolt of the

${ }^{1}$ Abreviaturas: AGS (Archivo General de Simancas); MNL (Magyar Nemzeti Levéltár [Archivo Nacional de Hungría, Budapest]), MKA (Magyar Kamara Archivuma [Archivo de la Cámara Húngara, Budapest]); ÖStA (Österreichisches Staatsarchiv, Viena), FHA (Finanz- und Hofkammerarchiv), HHStA (Haus-, Hof- und Staatsarchiv); RAH (Real Academia de la Historia). Quisiera expresar mi agradecimiento al Dr. Evaristo C. Martínez-Radío Garrido y al Dr. Rubén González Cuerva por su amabilidad al revisar el texto y corregir mis lagunas lingüísticas.
\end{abstract}


remaining 400 soldiers and the disobedience and dissolution of the first Old Tercio of Naples in Hungary during 1553. It also shows in a more detailed manner the last years of Bernardo de Aldana's life, including his release from jail in Hungary, his new military assignments in Italy and his dead in the battle of Djerba in 1560. As a further aspect, the study reflects the historical parallelism between the two distant anti-Ottoman military borders: the Mediterranean and Hungary.

KEY WORDS: Spanish Tercios, History of Hungary, Ottoman wars in Hungary, Military Revolts, Tercio of Naples

\section{MOTÍN DE LOS ESPAÑOLES}

La expedición de Bernardo de Aldana es uno de los eventos más curiosos e importantes para la historia de Hungría entre 1548 y 1553. La fuente primaria es la Expedición militar de Bernardo de Aldana a Hungría en 1548, que se halla en la Biblioteca del Monasterio de El Escorial ${ }^{2}$, de autor desconocido. ${ }^{3}$ La obra fue publicada por primera vez por Antonio Rodríguez Villa en $1878,{ }^{4}$ más tarde por el polaco Félix Rozanski. ${ }^{5}$ Esa última versión en lengua polaca es bien extraña, pues la vida de Aldana no tiene ninguna relación directa con la historia de Polonia. El tercio español luchaba en tierras húngaras, aunque es verdad que la viuda del rey Juan I Szapolyai (1526-1540) era la hija del rey polaco Segismundo el Viejo (1506-1548). La primera edición crítica fue la húngara - obra del hispanista László Scholz y del difunto historiador Ferenc Szakály. ${ }^{6}$ Recientemente Francisco Escribano Martín público nuevamente la Expedición en español.

\footnotetext{
${ }^{2}$ Real Biblioteca del Monasterio San Lorenzo de El Escorial, códice V.II.3, folios 177-234.

${ }^{3}$ Pese a que ciertos estudiosos consideran al hermano, fray Juan Villela de Aldana como su autor, lo más probable es que debamos descartarlo, pues el autor de la expedición habla en tercera persona sobre el fraile incluso relata como testigo la escena en la que Juan Villela de Aldana besa las manos del rey Fernando I. “...Estas fueron las palabras formales y sustanciales que S. M. clementísima dijo, porque las oí estando bien cerca de él. Luego, después de comer, su hermano de Aldana les fue a besar las manos por la merced y gracia que les había hecho...”. En Francisco Escribano Martín, ed., La expedición del maestre de campo Bernardo de Aldana a Hungría en 1548 (Madrid: Ed. Miraguano, 2010), 210. Sobre la cuestión del autor véase: Zoltán Korpás, "La correspondencia de un soldado español de las guerras de Hungría a mediados del siglo XVI. Comentarios al diario de Bernardo de Aldana (1548-1552)", Hispania 206 (2000): 904 y también Escribano Martín, La expedición, 15-18.

${ }^{4}$ Antonio Rodríguez Villa, ed., Expedición del maestre de campo Bernardo de Aldana à Hungría en 1548 (Madrid: Ed. Medina, 1878).

${ }^{5}$ Feliks Rozanski, ed., Wyprawa na Wegry Bernarda Aldany jenerała kawaleryi hisæpanskiej w latach 15481556 (Krakow: Redakcja "Przeglądu Polskiego", 1882).

${ }^{6}$ Ferenc Szakály, ed., Bernardo de Aldana magyarországi hadjárata [1548-1552] (Budapest: Európa Könyvkiadó, 1986).

${ }^{7}$ Escribano Martin, La expedición, passim.
} 
En 1999 el profesor Ferenc Szakály me facilitó una documentación curiosísima: la correspondencia del maestre de campo Bernardo Villela de Aldana y otras cartas relacionadas, halladas en el Haus-, Hof- und Staatsarchiv de Viena, Austria. La correspondencia de Aldana, escrita durante su permanencia en Hungría, había sido publicada por mí en la revista archivística húngara Fons. ${ }^{8}$ También salió a luz un estudio en español sobre la misma correspondencia, publicado en Hispania en 2000, pero sin incluir la documentación. ${ }^{9}$ Las fuentes ofrecidas por el profesor Szakály contenían una segunda parte muy valiosa: se trata de unas docenas de cartas con referencia al motín hasta ahora desconocido de cuatrocientos españoles en marcha de Transilvania a Viena entre marzo y septiembre de $1553 .{ }^{10}$ Esa documentación está en estrecha relación con la descomposición y retirada del ejército real de Fernando de Austria (1526-1564), encabezado por el maestre de campo general Giovanni Battista Castaldo, que se hallaba en aquel entonces en Transilvania. ${ }^{11} \mathrm{Mi}$ intento es hacer conocer al público español unos acontecimientos únicos, pues raras veces se documenta tan detalladamente y a fondo una sublevación o motín de los tercios españoles. Incluso, no me consta que hasta hoy no se ha hallado una cantidad tan rica de fuentes originales (unas 45 cartas) que contaran sucesos similares en la Europa centrooriental. ${ }^{12}$

\section{Contexto histórico}

Antes de centrarme en el motín de los españoles merecerá la pena recordar algunos aspectos del contexto histórico ${ }^{13}$ : Aldana había llegado a Hungría, que estaba

\footnotetext{
${ }^{8}$ Zoltán Korpás, "Egy spanyol zsoldosvezér levelei a XVI. század közepén vívott magyarországi háborúkról. Adalékok Bernardo de Aldana magyarországi tevékenységéhez (1548-1552)”, Fons 1-2 (1999): 3-129.

${ }^{9}$ Korpás, La Correspondencia, 881-910.

10 Zoltán Korpás, “Ami a magyarországi hadjárat után történt. Bernardo de Aldana és a spanyol zsoldosok sorsa 1552 után”, Fons 3 (2005): 379-398.

11 Giovanni Baptista Castaldo fue general supremo de Hungría desde el 27 de abril de 1551. Véase: Géza Pálffy, A császárváros védelmében. A gyôri kapitányság története 1526-1598 (Győr: Gyơr-Moson-Sopron Megye Gyới Levéltara, 1999), 230. Véase también la obra contemporánea del secretario de Castaldo: Ascanio Centorio, Commentarii della guerra di Transilvania (Venecia, 1566).

12 Una de las causas por las que se habían conservado esa cantidad de fuentes, podría ser el pleito que se había iniciado contra Aldana en aquellos meses con motivo de haber abandonado el castillo de Lippa, en Transilvania, cayendo así en manos otomanas. Véase la carta de Fernando I al archiduque Maximiliano, hijo suyo, sobre el comienzo del pleito. Viena, 22 de septiembre de 1553. ÖStA HHStA Ung. Akten Allg. Akten, Fasc 70. Konv. A. fol. 56. Sobre el pleito véase más detalladamente la obra sobre la justicia contra los "rendidores de castillos" de Géza Pálffy, "Várfeladók feletti itélkezés a 1617. századi Magyarországon”, Levéltári Közlemények 68:1-2 (1997): 216-217.

13 Véase Teréz Oborni, "From Province to Principality: Continuity and Change in Transylvania in the First Half of the Sixteenth Century", en Fight Against the Turk in Central-Europe in the First Half of the 16th Century, ed. István Zombori (Budapest: Historia Ecclesiastica Hungarica Alapítvány, 2004), 165180; Géza Pálffy, The Kingdom of Hungary and the Habsburg Monarchy in the Sixteenth Century (Boulder, Colorado: Social Science Monographs-Wayne, New Jersey: Center for Hungarian Studies and Publications, Inc.-New York, Columbia University Press, 2009) (=East European Monographs, DCCXXXV; CHSP Hungarian Studies Series, 18). Sobre el estatus político del principado de Transilvania véase Teréz Oborni, "Between Vienna and Constantinople: Notes on the Legal Status of
} 
inmersa en una situación complicadísima. Después de la batalla de Mohács y del fallecimiento del rey Luís II de Jagellón (29 de agosto de 1526) la corona de San Estaban estaba siendo disputada por dos pretendientes: Fernando I de Austria y Juan (I) Szapolyai, voivoda de Transilvania - ambos coronados con la corona de San Esteban, adquiriendo legitimidad de tal manera. Detrás de los dos reyes locales se vislumbraban las potencias más grandes de Europa: el emperador Carlos V (1516/1519-1556) sostenía a su hermano Fernando y, por otra parte, Solimán el Magnífico (1520-1566) apoyando al rey Juan. Para la Sublime Puerta era ideal alimentar una guerra interna que, por una parte, debilitaba la presencia de los Austria en Europa Central y por otra, le dejaba espacio para intervenir con su potente ejército cuando lo considerara más oportuno. Así llegamos a 1541, cuando, a consecuencia de las negociaciones anteriores entre los dos reyes húngaros, Fernando y Szapolyai (la paz de Várad de 1538), Solimán - tomando una decisión estratégica - decidió ocupar la ciudad de Buda, situada en el centro del reino, bloqueando así el intento de unificación de las dos Hungrías cristianas bajo soberanía de Fernando y Juan respectivamente. Con ese paso crucial se había impedido la unificación y la paz de Várad quedaba en papel mojado, surgiendo de esta manera las tres Hungrías: la de Fernando I (occidente y norte), la de los partidarios de Szapolyai, muerto en 1540 (Transilvania y las llamadas Partes o Partium, territorios entre Transilvania y el río Tisza) y la de los otomanos (zonas centro y meridional).

Pero los soberanos de Transilvania y el rey Fernando no se habían resignado a la posible unificación de las dos Hungrías cristianas y tampoco a la anhelada expulsión de los otomanos del centro del país, sino que seguían manteniendo negociaciones secretas. A la vez, la década de 1540 se caracterizó también por nuevas conquistas otomanas cerca de Buda para proteger la ciudad recién ocupada; de esta manera fueron cayendo fortalezas importantes por la parte occidental del país, como Tata, Székesfehérvár (Alba Regia en latín) y Esztergom (Estrigonia) en 1543. Tata tenía una guarnición italiana, mientras que la sede arzobispal de Esztergom tenía a mil españoles y quinientos húngaros bajo mando de los capitanes Martín de Lazcano y Francisco de Salamanca. En cuanto a las intenciones cristianas, hay que mencionar la consolidación del poder de Fernando I en Hungría Superior (o sea, ciertas expediciones contra oligarcas húngaros por el norte del país que aprovechaban el vacío de poder). Algunas de ellas con participación militar española como, por ejemplo, la expedición del ejército real en 1545 con la participación de otro notable maestre de campo: Álvaro de Sande

the Principality of Transylvania", en The European Tributary States of the Ottoman Empire in the Sixteenth and Seventeenth Centuries, eds. Gábor Kármán y Lovro Kunčević (Leiden-Boston: Brill, 2013): 67-89. Teréz Oborni, "Die Plane des Wiener Hofes zur Rückeroberung Siebenbürgens 1557-1563", en Kaiser Ferdinand I. Ein mitteleuropaischer Herrscher, eds. Martina Fuchs, Teréz Oborni y Gábor Ujváry (Münster: Aschendorff, 2005): 277-298 [Geschichte in der Epoche Karls V. Band 5]. Una monografia recientemente publicada: Gábor Almási, Kees Teszelszky, Áron Zarnóczki, Szymon Brzeziński, Ildikó Horn, eds., A Divided Hungary in Europe. Exchanges, Networks and Representations, 1541-1699 (Newcastle upon Tyne: Cambridge Scholars, 2014). 
y su tercio de Lombardía ${ }^{14}$. Hagamos referencia también a Bernardo de Aldana, el español más destacado a causa de la Expedición publicada en español, polaco y húngaro. La primera parte de la Expedición de Aldana relata las luchas contra ciertos oligarcas húngaros por Hungría Superior en 1548-9. Durante este lapso de tiempo las dos Hungrías cristianas siguieron negociando sobre la posible unificación del país, un tema que preocupó diariamente a la elite política húngara durante décadas. Después del fracaso del intento de paz de Várad $(1538)^{15}$, el tratado de Nyírbátor en 1549 fue el punto de partida donde los representantes de Fernando (András Báthory, el conde Niklas Salm, Sigmund von Heberstein) y los de la familia Szapolyai (Jorge Martinuzzi o Monje Blanco $)^{16}$ acordaron iniciar el proceso de integración de las dos partes del reino bajo el cetro de los Austria. El ejército real, encabezado por el conde de Salm y, después de su muerte en 1550 en el castillo de Eger, por Giovanni Baptista Castaldo, se encaminó hacia Transilvania, ocupando y reconstruyendo primero el castillo abandonado de Szolnok (1550-1) a medio camino entre Transilvania y Buda. Luego, dejaron guarniciones en los castillos más importantes de Transilvania y de Partium (Temesvár, Lippa, Várad, etc.). Estos acontecimientos aparecen pormenorizadamente relatados en el libro de la expedición de Aldana, pues su tercio y él personalmente formaron parte del grueso de los sucesos. Pero las acciones políticas y militares de Fernando I eran contempladas con recelo no solo en Estambul, sino que también las bloqueaban en buena parte los mismos húngaros en Transilvania, opuestos al intento de unificación. En esta situación delicadísima, en 1552 los otomanos enviaron dos ejércitos para echar a los Austrias de Transilvania: el pachá de Buda ocupó los castillos cercanos a Buda y derrotó en la batalla de Palást a las reservas reales encabezadas por Erasmo Teuffel y Sforza Pallavicini, con destino a Transilvania. Mientras, el beylerbey de Belgrado envió su ejército para ocupar los castillos más importantes de Partium y Transilvania occidental. Castillos como Temesvár (Timișoara, Rumanía), Lippa (Lipova, Rumanía) o Szolnok no pudieron resistir y cayeron uno tras otro junto con sus guarniciones multinacionales (húngaros, alemanes, españoles del tercio de Aldana, italianos, bohemios, racianos ${ }^{17}$ ). Los dos ejércitos otomanos se unieron durante el otoño de 1552 frente al castillo de Eger, el único en esta cadena de desastres militares

${ }^{14}$ Zoltán Korpás, “Álvaro de Sande hadjárata Trencsén vármegyében - 1545”, en Redite ad Cor. Tanulmányok Sabin-Tóth Péter emlékére, eds. Lilla Krász y Teréz Oborni (Budapest: ELTE Eötvös Kiadó, 2008): 199-210.

15 Tampoco olvidemos que la paz de Várad no era una paz aislada y local: estaba profundamente insertada en el sistema de acuerdos y alianzas de Carlos V de 1538, cuando intentaba organizar la Santa Liga contra los otomanos y finalizar en Aguas Muertas/Niza la guerra contra Francisco I. Sobre las correlaciones entre la Liga de 1538, la batalla de Preveza y asedio de Castelnuovo y la paz de Várad véase: Zoltán Korpás, "Las luchas antiturcas en Hungría y la política oriental de los Austrias 1532-1541", en Fernando I, 1503-1564. Socialización, vida privada y actividad pública de un Emperador del Renacimiento, eds. Alfredo Alvar y Friedrich Edelmayer (Madrid: Sociedad Estatal de Conmemoraciones Culturales, 2004), 358-362.

${ }^{16}$ El rey Juan I de Szapolyai falleció el julio de 1540. Tras su fallecimiento, su mujer, Isabel de Jagellón, y el válido, cardenal Jorge Martinuzzi, gobernaron en nombre del rey niño Juan Segismundo de Szapolyai.

${ }^{17}$ Rasciano o raciano - nombre arcaico de los serbios. 
que resistía heroica y exitosamente un largo asedio. Como consecuencia de este ímpetu de las fuerzas otomanas, colapsó el sistema austriaco en Transilvania. Aislados de la Hungría real, con los castillos más importantes en manos otomanas, incluso corriendo el riesgo de una sublevación de los húngaros en Transilvania, se vieron forzados a abandonar la Hungría oriental. La política de Castaldo fracasó. Incluso, a causa del vacío de las arcas reales y de la falta de sueldos desde hacía más de 12-18 meses, buena parte del ejército real simplemente se negó a obedecer y empezó a salir de Transilvania sin permiso real. ${ }^{18}$

Ese es el contexto histórico del que participaron el maestre de campo Bernardo de Aldana y sus 1400 infantes españoles, llegados a Hungría en 1548 después de la guerra de Esmalcalda. Pasaron allí varios años en las luchas contra algunos oligarcas al norte de Hungría, formando parte del ejército real de Fernando I de Austria, y encabezado por el general Niklas Salm (1548-9). Después de haber invernado en Hungría, en 1550 los españoles, junto con los otros soldados de otras nacionalidades del ejército real, ocuparon el castillo de Szolnok, abandonado en tierra de nadie entre otomanos y húngaros. Aquí Aldana jugaba un papel decisivo en la construcción de una nueva fortaleza. Incluso, la desembocadura actual del río Zagyva en el río Tisza es el canal artificial (foso de la fortaleza) construido a iniciativa del propio Aldana. ${ }^{19}$

\section{La descomposición del ejército real de Castaldo y los soldados españoles}

Después de la muerte de Niklas Salm en diciembre de 1550, el ejército real sería liderado por Giovanni Baptista Castaldo y, como se ha mencionado, distribuido entre los castillos de Transilvania occidental y de Partium. La mayoría de los españoles, junto con los otros defensores húngaros y de otras naciones, cayeron durante los feroces asedios de los otomanos en 1552. Quedará como símbolo Gaspar de Castelví, el capitán de la compañía de los españoles, quien falleció heroicamente durante el segundo asedio de Temesvár en 1552, al lado del capitán del castillo István Losonczy, cuando los pocos defensores que quedaron salieron desesperadamente de la plaza, arruinada y cercada por el inmenso ejército otomano.

Otras compañías españolas permanecían en Lippa junto con otros soldados de origen húngaro y rasciano bajo el liderazgo de Bernardo de Aldana. Después de la caída de Temesvár, los otomanos siguieron avanzando rumbo a Lippa. Los defensores, al haber sido informados del peligro, abandonaron el castillo y el propio Aldana fue

${ }^{18}$ Sobre los acontecimientos en Transilvania y las guerras de 1551-2 véase recientemente Teréz Oborni, Az ördöngös Barát. Fráter György (1482-1551) (Pécs-Budapest: Kronosz, 2017); Barnabás Guitman, Zoltán Korpás, Ferenc Tóth, János B. Szabó, “A magyarországi török várháborúk nemzetközi háttere, 1547-1556" (=The International Background of the Ottoman War in Hungary, 1547-1556) Világtörténet 9:2 (2019): 253-293. Lajos Kropf, “Castaldo Erdélyben”, Hadtörténeti Közlemények 8-9 (18951896) en 5 entregas; Teréz Oborni, Erdély pénzügyei I. Ferdinánd uralma alatt (Budapest: Fons Könyvek, 2002). También Escribano Martín, La expedición, passim, Versión húngara: Szakály, Bernardo de Aldana, passim.

${ }^{19}$ Róbert Kertész y Zoltán Korpás, “A szolnoki végvár felépítése 1550-1552-ben és Bernardo Villela de Aldana ide kapcsolódó levelei”, TISICUM, Szolnok 22 (2013): 387-450. 
capturado por Giovanni Baptista Castaldo y acusado por este abandono no permitido. Desde ese momento Aldana perdió todo contacto con los miembros de su tercio, incluso con los españoles que abandonaron Transilvania y se amotinaron cerca de Viena, tema de ese estudio. O sea, no es probable que la correspondencia sobre el motín hubiera sido parte de la documentación del proceso legal iniciado contra Aldana por lesa majestad.

Sobre el ejército real de Castaldo, el cronista Wolfgang Bethlen escribió lo siguiente en su libro sobre la Historia de Transilvania:

En aquel entonces los soldados de Fernando se amotinaban constantemente a causa de las pagas atrasadas y se escaparon de las banderas. Cuatro mil de españoles hicieron lo mismo, negligando los órdenes de su general Castaldo. Levantaron sus banderas en camino hacia Viena, prendieron fuego, pillaron, saquearon y violaron los pueblos en ruta. $^{20}$

Las causas de los motines son bien conocidas: el fracaso de la unificación de las dos Hungrías y la caída de un gran número de castillos en manos otomanas en 1551-52. A consecuencia del cambio político en Transilvania y también por los enormes retrasos de paga durante los comienzos de 1553, la mayoría de los soldados de diferentes naciones empezó a salir del Principado con o sin permiso de sus superiores. Respecto a las fuentes del siglo XVI, raras veces tenemos la suerte de poseer tan rica documentación, en este caso 45 cartas que arrojan luz sobre el motín y saqueo por parte de cuatrocientos españoles (y no cuatro mil, como escribía el cronista Bethlen). Disponemos de datos del invierno de 1552 según los cuales los mercenarios de Castaldo ya habían atormentado a los vecinos de ciertas ciudades de Transilvania, habían negado la obediencia al rey y habían pedido permiso para salir del Principado. ${ }^{21}$ Los soldados, animados y enfurecidos por sus oficiales, habían marchado tras saquear el castillo de Déva (Deva, Rumanía) en Transilvania los primeros días de enero de 1553. Ni siquiera la orden de Castaldo fechada a 10 de enero de 1553, amenazando a los infractores con la pena de muerte, había sido capaz de frenar la salida ilegal de los soldados.

A comienzos de 1553 ciertas compañías del descompuesto ejército real se retiraron de Transilvania de manera desorganizada. A mediados de enero, algunos

20 "Abban az idöben Ferdinánd katonái a zsold elmaradása miatt Magyarországon és Erdélyben lépten-nyomon fellázadtak, a zászlók alól megszölktek. Négyezer spanyol ugyanazon okból, semmibe véve vezérïk, Castaldo parancsát, a zászlókat felemelve Bécs felé vetette útját, abol gyújtogattak, raboltak, fosztogattake és erószakoskodtak a néppel.” en Farkas Bethlen, Erdély története (Budapest-Kolozsvár: Enciklopédia Kiadó, 2002), vol. II, 183. (=Wolfgang Bethlen: Historia de rebus Transsylvanicis Cibinium, 1782).

${ }^{21}$ Según los datos de la historiadora Teréz Oborni, el tesorero de Transilvania Peter Haller se quejaba a finales de 1552 por la falta de pagas y abastecimiento que sufrían los soldados reales. Desde principios de 1553 el maestre de campo general Castaldo acudió varias veces al rey Fernando para obtener el permiso de sacar sus tropas de Transilvania. Véase Samu Barabás, "Erdély történetére vonatkozó regesták 1551-1553", Történelmi Tár (1891-1892), 6 entregas, especialmente los registros publicados en vol. 15:4: 653-682 respecto a la situación de Castaldo, la salida de los españoles de Transilvania y en general sobre la descomposición del ejército real. 
españoles del tercio de Aldana partieron de Kolozsvár (Cluj, Rumanía). Temiendo un motín general de los soldados, el mismo rey Fernando I dio el visto bueno para que las tropas reales salieran de Transilvania. Sin embargo, en aquellos días estos españoles ya estaban en camino con banderas alzadas. Sobre el 7 de febrero cruzaron el rio Tisza. La desobediencia era evidente y el rey ordenó que se cerraran los pasos y se arrestara a los soldados sin salvoconducto. Pero ni siquiera el mismo maestre de campo general Castaldo, perseguía a sus indisciplinados soldados. Él abandonó Transilvania a comienzos de marzo. Suponemos que el general italiano no tenía mucha influencia sobre los hombres de Aldana, dado que él fue quien anteriormente había ordenado el arresto del maestre de campo español.

\section{...y estalla el motín}

Los amotinados cruzaron toda Hungría Superior (actualmente parte oriental y central de Eslovaquia) Y llegaron a la ciudad de Rózsahegy (Rozemberok, Eslovaquia), en el condado de Liptó. La ciudad había sido saqueada varias veces, primero por los alemanes y luego por los españoles. ${ }^{22}$ Desde allí, los soldados del tercio de Aldana se dirigieron al sur. Hacia el 24 de marzo de 1553 unos 300-400 españoles llegaron a la ciudad de Modor (Modra, Eslovaquia), en el condado de Pozsony (Posonio, Bratislava, Eslovaquia). ${ }^{23}$ Por aquel entonces Modor era feudo del aristócrata Kristóf Országh. Debido al que los soldados de Aldana ya llevaban más de 14 meses sin recibir paga alguna $^{24}$, saquearon y ocuparon la ciudad rápidamente ${ }^{25}$. Después, incluso obtuvieron 70 monedas de oro más como tributo de la ciudad. ${ }^{26}$ Los vecinos de Modor explicaron detalladamente los daños causados y los sucesos en una relación enviada al rey Fernando I. Los españoles permanecieron dieciocho días en la ciudad, y durante este tiempo los militares consumieron todas las reservas almacenadas de vino y víveres. Lo que no fue consumido fue destruido y quemado, incluso los objetos personales de los vecinos fueron robados. Varios edificios y casas fueron incendiados y arruinados. El daño causado a Modor en total alcanzó los 1370 florines de oro. ${ }^{27}$

${ }^{22}$ Los vecinos de la ciudad se quejaban ante Fernando I de que los españoles y alemanes que deambulaban el país causaban enormes daños; incluso pedían al monarca que enviara un comisario para comprender el grado de destrucción y quedar exentos de pagar los impuestos por un par de años. Véase la carta de los vecinos de Rózsahegy (Rozemberok, Eslovaquia) a Fernando I. 1553. s.d., MNL, MKA, E 211 Lymbus, 115. cs., 1. t. fol. 375.

${ }^{23}$ El número de los soldados de 300-400 fue estimado por Sforza Pallavicini. Véase su carta a Fernando I, Récse, 1 de abril de 1553. ÖStA HHStA Ung. Akten Allg. Akten. Fasc. 70. Konv. B. fol. 77-80. fol. 2-6.

24 Sforza Pallavicini a Fernando I, Posonio, 14 de abril 1553. ÖStA HHStA Ung. Akten Allg. Akten. Fasc. 70. Konv. B fol. 38.

${ }^{25}$ La carta de los alcaldes de Modor al obispo de Győr, Ferenc Újlaki. Modor, 24 de marzo de 1553. ÖStA HHStA Ung. Akten Allg. Akten. Fasc. 70. Konv. A. fol. 226.

${ }^{26}$ Sforza Pallavicini a Fernando I. Récse, 13 de abril de 1553. ÖStA HHStA Ung. Akten Allg. Akten. Fasc. 70. Konv. B. fol. 77-80.

${ }^{27}$ Humillima supplicatio pauperum oppidanorum de Modor. 1553. május 18. MNL MKA E 210 Miscellanea, Militaria, 59. t. 1. sz. 
Daba la impresión de que una de las causas del motín de los soldados hispanos era que habían salido de Transilvania sin un verdadero líder, pues en aquel entonces Aldana ya había sido detenido como consecuencia del abandono del castillo de Lippa y el control sobre el resto de su tercio fue conferido del maestre de campo a un comisario real de origen español o portugués: Stephanus Arribadeneira. ${ }^{28}$ En una breve carta húngara, el comisario Ribadeneira aparece como una persona débil y sin buena reputación. ${ }^{29}$ Pese a ello, la carta considera también que era un individuo confiable pero que, a la vista de una sublevación, no sería capaz de controlarla.

El 25 de marzo, días después del saqueo de Modor, Ribadeneira escribió una carta a Ferenc Újlaki, obispo de Győr (Raab en alemán, Javarino en las fuentes españolas, Hungría actual), rogándole que enviara su mensaje al rey Fernando I. En él exponía el vergonzoso comportamiento de los españoles y aseguraba que personalmente no tenía nada que ver con el motín; al contrario, sufría a causa de ello pues lo tenían capturado y, apartándose de los sublevados, le enfatizó su lealtad al monarca. $^{30}$

\section{La junta de crisis y las negociaciones con los amotinados}

El obispo Újlaki, a tenor de las malas noticias, tomó decisiones con vehemencia. En primer lugar, informó al rey el 25 de marzo de que los españoles habían causado más daño en las propiedades de Kristóf Országh que los mismos otomanos. ${ }^{31}$ Por otro lado, convocó en Pozsony (Bratislava, Pressburg, Posonio, capital actual de Eslovaquia) a los capitanes de las tropas reales de la región para que acordaran un plan de acciones contra los españoles amotinados. El 27 de marzo llegó a Pozsony Sforza Pallavicini, maestre de campo general de Hungría, quien participó también en la reunión que tuvo lugar en ese mismo día. Participaron otros potentados del país, como el mencionado obispo Újlaki de Zagreb, Paulus Gregoriánczi, Ferenc Thurzó, obispo de Nyitra (Nitra, Eslovaquia actual), conde Eck Salm und Neuburg, e incluso un español no amotinado: Luis de Osorio, capitán del tercio de Aldana. ${ }^{32}$ A Pallavicini le acompañaban 200 soldados a caballo y otros tantos a pie. Basta con echar un vistazo

\footnotetext{
${ }^{28}$ Stephanus Arribadeneira al obispo de Győr, Ferenc Újlaki. 25 de marzo de Modor. ÖStA HHStA Ung. Akten Allg. Akten. Fasc. 70. Konv. A. fol. 221.

${ }_{29}$ “Az komissarius jámbor volna...”. S.d. ÖStA HHStA Ung. Akten Allg. Akten. Fasc. 70. Konv. A. fol. 227.

30 ibid. fol. 221. Stephanus Arribadeneira a Ferenc Újlaki obispo de Győr. Modor, 25 de marzo de 1553.

31 „ex litteris quas cum presentibus ad vestram maiestatem missi quo pacto copie hispanos in bonis domini Orszagh agant. Maiestas vestra credere dignibatur que misera plebs hostes thurcas non ita horribiliter...” ibid. fol. 225 . Ferenc Újlaki a Fernando I. Posonio, 25 de marzo de 1553.

32 Sobre Luis de Osorio véase: Christopher F. Laferl, Die Kultur der Spanier in Österreich unter Ferdinand I. 1522-1564 (Wien: Böhlau, 1997), 257-258, 265. Después de la muerte del capitán Luis de Ordoñez, Osorio fue nombrado por Fernando I como sucesor en el empleo de capitán de una compañía del tercio. Véase la carta de Fernando I a Mathias Fuchs, pagador general del ejército real en Hungría. Augsburg, 14 de febrero de 1551. ÖStA Finanz- und Hofkammerarchiv, Hofkammerachiv Gedenkbücher Österreich Band 67. fol. 27v-28r.
} 
a la "junta de crisis" para darse cuenta del grado de alarma en el gobierno: el obispo Újlaki era el gobernador real de Hungría y el obispo Thurzó el presidente de la Cámara Húngara (institución responsable de la Hacienda húngara), los dos mayores cargos del reino. El italiano Pallavicini también tenía una alta responsabilidad: siendo mariscal general de Hungría con sede en el castillo cercano de Győr, estaba encargado de la defensa militar de toda la región occidental de Hungría, que actuaba como antemuralla de la ciudad imperial de Viena. El español Osorio, por su parte, conocía a fondo a sus compatriotas amotinados y contribuía a las negociaciones con su experiencia militar y personal. El conde Eck Salm estaba presente supuestamente porque ya en aquel entonces se le había conferido el empleo de capitán de la ciudad de Pozsony. Los miembros de la junta llegaron al acuerdo de enviar a Johannes Barbel como agente para trasmitir la carta española de Osorio en que se conminaba a los amotinados a volver a la obediencia. Incluso enviaron una relación al rey Fernando en que proponían al monarca que, en caso de no poder llegar a un acuerdo con los soldados hispanos, armar a todos los vecinos disponibles de los condados vecinos contra los amotinados. ${ }^{33}$ Como se trasluciría en otras cartas posteriores, los líderes políticos y militares tenían mucho miedo al valor y disciplina militar de unos centenares de españoles en las cercanías de Viena. ${ }^{34}$

Pasaron unos días en espera y a comienzos de abril daba la impresión de que el motín se solucionaría sin complicación alguna. Sforza Pallavicini enviaba su relación a Fernando comentando que, según lo acordado el 27 de marzo, empezaron a negociar con los amotinados y él personalmente se encontró con el representante de los españoles, un tal Sancho Cota. ${ }^{35}$ Es curioso que tengamos noticias de un Sancho Codo o Coda desde los años cuarenta, quien había servido en Hungría muchos años antes de la llegada del tercio de Aldana. Podemos suponer que es la misma persona y que en un momento dado se unió al tercio de Aldana. Según Pallavicini, los hispanos estaban dispuestos a volver al orden, con lo que en los últimos días de marzo ya se negociaba en el campo de los amotinados en Modor para que volvieran al servicio del rey. Los españoles prometieron presentar sus demandas por escrito y remitirlas lo más rápido posible a Pozsony. Vistas por Pallavicini, las consideró justas y aceptables y las adjuntó a la carta despachada a Fernando. Respecto a su contenido, los españoles exigían pagas mensuales según los acuerdos originales, así como que se hicieran revistas regulares cada seis meses. Pedían también que los oficiales no entraran en el campamento de los amotinados durante cuatro días mientras ellos arreglaran las cuentas pendientes entre

33 ÖStA HHStA Ung. Akten Allg. Akten. Fasc. 70. Konv. A., fol. 235. Los miembros de la junta militar a Fernando I. Posonio, 27 de marzo de 1553. El mismo día el obispo Újlaki envió su relación personal a Fernando I. A esa carta adjuntó la petición de ayuda de los alcaldes de la ciudad de Modor. Ibid, fol. 231.

${ }^{34}$ Sobre el tercio y su valor militar véase las obras clásicas de René Quatrefages, Los tercios (Madrid: Fundación Universitaria Española, 1983) y Geoffrey Parker, The Army of Flanders and the Spanish Road (London: Cambridge University Press, 1972); Enrique Martínez Ruíz, Los soldados del Rey: los ejércitos de la Monarquía Hispánica (1480-1700) (Madrid: Actas 2008).

${ }^{35}$ Laferl, Die Kultur, 231. Menciona el nombre de Sancho Cota, según lo cual Cota permanecía en la ciudad húngara de Komárom entre 1539 y 1547. 
ellos. La petición de que los oficiales solo pudieran castigar a los soldados españoles después de que el maestre de campo investigara cada asunto y tomara una decisión, para Pallavicini era inaceptable. Según las estimaciones del italiano, el número de los españoles oscilaba entre 300 y 400 . Aconsejó a Fernando que el mismo rey escribiera una carta aceptando las peticiones porque, de otra manera, los españoles no creerían que el acuerdo se respetaría. Incluso comentó que le parecía justa e importante la idea de Fernando de despedir del servicio a los españoles tras una muestra general. Según su opinión el lugar apropiado para guarnicionar y hacer la revista era la ciudad cercana de Pápa (Hungría). Aconsejó también designar al capitán Luis de Osorio para distribuir la paga de los amotinados ya que era leal al rey. Esta medida parecía idónea debido a que incluso los españoles declararon que no obedecerían a ningún otro oficial, solo a sus capitanes de origen español. En su larga carta, Pallavicini comentó también que retiraría sus tropas a Győr a la espera de nuevas órdenes reales y que encargaría a Christopher Link que abasteciera a los españoles amotinados. ${ }^{36}$ En caso de que Su Majestad no estuviera conforme en aceptar las exigencias de los soldados, Pallavicini utilizaría la guarnición de Viena (cohors Viennensis) y los veteranos que se hallaban allí para batir a los españoles. Además, contaba con unos 300 soldados húngaros a pie. A la vez puso énfasis en que, al contrario de la opinión de la reunión de la junta del 27 de marzo, él personalmente no se fiaba nada de la fuerza militar de los vecinos de los alrededores. En caso de alzar aquellos contingentes irregulares, le parecía más oportuno mandarlos a su casa en vez de a luchar contra españoles expertos en el arte de la guerra, debido a que reconocía el valor militar de los amotinados y tampoco quería derramar la sangre - tan cerca de tierras otomanas - de los vecinos inexpertos en lucha contra "profesionales". Añadía que los soldados alemanes a pie bajo las órdenes del capitán Karl Rhuen, que se hallaba en el castillo de Györ, también le parecían un contingente oportuno para enfrentarse a los españoles, aunque - según el comentario de Pallavicini - aquellos también eran pobres y no recibían la paga desde hacía muchos meses. Los alemanes de Rhuen en aquellos días pasaban cerca de Rajka, a poca distancia de Modor. ${ }^{37}$

Paralelamente, los españoles amotinados en Modor declararon que ellos consideraban que no habían abandonado el servicio al rey Fernando y seguían siendo fieles a su persona. ${ }^{38}$ Pallavicini, en su respuesta escrita en italiano, conminó a los españoles a cumplir con sus juramentos y volver al servicio en orden. Puso énfasis en que a su agente delegado, Sancho Cota, no le sucediera cosa alguna y ordenó a este que

36 Sobre el comisario general de alimentación (en alemán General Proviantmeister) véase István Kenyeres, “A magyarországi végvárak és a mezei hadak élelmezési szervezetének archontológiája a XVI. században”, Fons 11:2 (2004): 336.

${ }^{37}$ Las exigencias de los soldados españoles enviadas a Sforza Pallavicini. Modor, 30 de marzo 1553. ÖStA HHStA Ung. Akten Allg. Akten. Fasc. 70. Konv. B fol. 7. la larga relación de Sforza Pallavicini a Fernando I. Récse, 1 de abril de 1553. ibid, fol. 2-6.

${ }^{38}$ Las exigencias de los soldados españoles enviadas a Sforza Pallavicini. Modor, 30 de marzo 1553. ÖStA HHStA Ung. Akten Allg. Akten. Fasc. 70. Konv. B fol. 7. "En quanto a la obedencia, nunca nosotros avimos salido della, sino que estamos oy tanto en ella y estaremos, como siempre avemos estado...". 
abasteciera a los españoles hasta recibir nuevas órdenes. Expresó también su esperanza en que el rey aceptaría las exigencias de los españoles y les otorgara merced real general. Repitió también que sus peticiones le parecían justas y aceptables, aunque el punto en que los soldados pedían que se les pudiera condenar únicamente con permiso del maestre de campo le parecía contrario a la tradición militar española. ${ }^{39}$

Parece que se ganó la confianza de los españoles: en otra carta de 31 de marzo, los amotinados se refieren a Pallavicini como gran amigo de la nación española, quien contribuyó más que cualquier otro en apaciguarlos. Pedían a Pallavicini que interviniera ante el monarca para conseguir una audiencia en la que pudieran desmentir todas las calumnias y mentiras vertidas sobre ellos. En la misiva repetían las condiciones presentadas, añadiendo que, como algunos querían quitarles sus banderas, exigían que la gracia real incluyera que pudieran conservarlas. Informaron a Pallavicini que dos de sus camaradas habían sido enviados a la corte real y, hasta que no volvieran, los amotinados no causarían ningún alboroto ni daño durante aquellos 4 o 5 días. ${ }^{40}$

Pero otros oficiales estaban muy molestos con que los soldados desobedientes y amotinados tuvieran la "cara dura" de presentar demandas y de enviar delegados al rey. Uno de estos oficiales era el mismo capitán Luís de Osorio, leal a Pallavicini. Osorio expresó su indignación y comentó que los soldados alemanes habían llegado a Pozsony acompañados con piezas de artillería e, incluso, esperaba un contingente de soldados húngaros que estaban en camino. Subrayó que, teniendo en cuenta la experiencia y valor militar de los españoles, el número de arcabuceros y armas de fuego era poco e inapropiado para arriesgarse a un choque armado. Pidió a Pallavicini que le enviara más armas de fuego y arcabuceros porque, en caso de enfrentamiento, solo ellos serían capaces de contrarrestar la ventaja española. ${ }^{41}$

\section{... y crece la tensión}

Resulta que, pese a las buenas señales iniciales, ambas partes no llegaron al acuerdo en un primer momento. Aunque los españoles expresaban su confianza en Pallavicini, el italiano se hallaba en una situación delicada. Se trasluce de su correspondencia que no quería arriesgarse a una escaramuza contra los españoles con su hueste formada por soldados de diferentes naciones, sin experiencia en colaboración previa y de diferentes adiestramientos militares, en general inferiores a los hispanos. A la vez, quería evitar el derramamiento de sangre cristiana tan cerca de Viena y de los otomanos. Podríamos decir que estaba en un brete pues, por una parte, le parecían justas las exigencias de los españoles insatisfechos por su falta de pagas durante más de 14 meses, pero, por otro lado, no lo podía consentir debido a la disciplina militar, a la lealtad y a la reputación del soberano. Ese dilema se detecta a lo largo de toda la correspondencia del italiano dirigida tanto al rey como a los españoles.

\footnotetext{
${ }^{39}$ Sforza Pallavicini a los soldados españoles. Posonio, 31 de marzo de 1553 ibid, fol. 9.

40 Otra carta española de los amotinados a Sforza Pallavicini. Modor, 31 de marzo de 1553. ibid, fol.

${ }^{41}$ Luís de Osorio a Sforza Pallavicini. Posonio, 8 de abril de 1553. ibid, fol. 40.
} 11. 
Suponemos que esta situación también pudiera ser conocida por los soldados españoles pues, después de esperar algunos días en Modor la respuesta del rey, el 8 de abril transmitieron otra carta a Pallavicini de un tenor totalmente diferente. Se sentían ofendidos porque Pallavicini no fuera capaz de cumplir su promesa, así como indignados porque aquel les remitiera al capitán del tercio Luis de Osorio, con quien los amotinados ya hacía tiempo que mantenían mala relación. Incluso acusaban a Osorio de exigirles entregar las banderas. Dieron un ultimátum según el cual volverían al orden y entregarían las banderas solo en caso de ver sus exigencias por escrito y cumplidas, al igual que recibir el dinero de sus retrasadas pagas ${ }^{42}$.

La situación comenzó a empeorar. Pallavicini contó al rey la mala relación entre los soldados españoles y su capitán Osorio. Sobre el 8 de abril llegaron los capitanes húngaros György Paksy ${ }^{43}$ y Ferenc Kövy con otros trescientos caballos húngaros. El número de soldados crecía y a Pallavicini le parecía más factible un choque armado contra los españoles. Al mismo tiempo, estos salieron de Modor y, ante el fracaso de las negociaciones, se dirigieron a Pozsony, entrando en Szentgyörgy (Sankt Georgen, Svätý Jur, Eslovaquia). Pallavicini, al conocer la noticia, envió 300 caballos a Rajka para cortarles el camino. Incluso llamó a otros 200 soldados a caballo para incrementar su fuerza e impedir el paso de los hispanos por el Danubio, pues temía que se encaminaran directamente a la sede imperial de Viena ("recta via ad Maiestatem Vestram pergere volunt".) Si conseguía que no cruzaran el río, se quedarían desabastecidos, lo que conllevaría el fin del motín - opinaba Pallavicini. ${ }^{44}$

Los movimientos de los hispanos obligaron también al italiano a mover sus tropas. El 10 de abril salió de Győr hacia el oeste y el 13 de abril escribió a Fernando I comentando que en Pozsony se veían barcos en la ribera izquierda del río. Mientras, los amotinados se acercaron al paso del río, aunque la guardia puesta en la orilla les impidió cruzarlo. La guardia constaba de hispanos y de caballos ligeros húngaros (húsares) liderados por Osorio y por Francisco de Salamanca, a la par que llegaron refuerzos de infantes desde Viena. Pallavicini distribuyó sus tropas. 200 soldados a caballo y un cuerpo de piqueros estaban bajo órdenes de Osorio en la ribera izquierda del Danubio; Salamanca por su parte mandaba otros 200 caballos mientras que los alemanes a pie se posicionaron en la ribera derecha del Danubio. Pallavicini se situó cerrando el camino hacia Győr a la espera de otras compañías de refuerzo que salían de Pápa. ${ }^{45}$

Los amotinados tampoco esperaron después del fracaso en cruzar el río. Caminaron hacia Stomfa (Stampfen, Stupava, Eslovaquia) y luego tornaron hacia Marchegg (Austria) para cruzar el Morava, río fronterizo entre el Reino de Hungría y Austria/Moravia. Pallavicini temía que los amotinados pudieran saquear fácilmente

\footnotetext{
${ }^{42}$ Los soldados españoles a Sforza Pallavicini. Modor, 8 de abril de 1553. ibid, fol. 42.

${ }^{43}$ Sobre el capitán de caballería György Paksy en el castillo de Győr véase: Pálffy, A császárváros, 253.

${ }^{44}$ Sforza Pallavicini a Fernando I. Győr, 10 de abril de 1553. ÖStA HHStA Ung. Akten Allg. Akten. Fasc. 70. Konv. B. fol. 33.

45 Giovanni Baptista Castaldo a Fernando I. Posonio, 14 de abril de 1553. ÖStA HHStA Ung. Akten Allg. Akten. Fasc. 70. Konv. B. fol. 37. Sforza Pallavicini a Fernando I. Posonio, 14 de abril de 1553. ibid, fol. 38 .
} 
todas las aldeas y ciudades de la región de Marchfeld (llanura de Moravia al noreste de Viena), al contar con una mala defensa y estando ya en tierras del Sacro Imperio, y que después tuvieran la oportunidad de escaparse. A la vista de la nueva situación militar, el ejército del italiano parecía ser pequeño para cumplir la tarea y proteger un vasto territorio como Marchfeld contra los españoles, que habían escapado de la trampa en Pozsony. Pallavicini dejó la infantería que llegaba de Viena con cuatro falconetes en los suburbios de Pozsony para impedir el posible paso de los españoles por el Danubio. Mientras, los 200 caballeros ligeros de Hungría encabezados por György Paksy y Ferenc Zay, capitán general de los nasades ${ }^{46}$ (embarcaciones militares fluviales) de Győr, fueron guarnicionados cerca de esta ciudad. Incluso, el general italiano comentó en su carta a Fernando I que era necesario demostrar paciencia con los amotinados porque, en caso contrario, no volverían a la obediencia sin derramar sangre, lo que le parecía muy peligroso teniendo los territorios otomanos sólo a unas millas de distancia. Subrayó que los alemanes que le acompañaban eran poco fiables, pues también carecían de pagas desde hacía meses y pidió refuerzos para controlar la situación. Añadía que los alemanes - aun poco fiables - no podrían ser retirados hasta que no acabara el motín de los españoles. ${ }^{47}$

Pero el motín obligaba también a que el propio Giovanni Baptista Castaldo fuera a Pozsony, llegando el día 13 de abril. Rápidamente inició un encuentro con los capitanes de los españoles leales y, analizando la situación, consideraron que los amotinados no estarían dispuestos a volver al servicio real pese a las muchos órdenes que se les habían enviado. Los insatisfechos soldados rechazaron la continuación de las negociaciones exigiendo que se respetaran las condiciones originales. ${ }^{48}$

Pero el valor militar de los sublevados requería mucha cautela por parte de los líderes del ejército real. Tras la escaramuza de Pozsony, tanto Castaldo como Pallavicini aconsejaron al rey Fernando que los vecinos de los territorios austriacos cercanos también se armasen para impedir los posibles saqueos y el paso de los amotinados al occidente de Austria o Bohemia. ${ }^{49}$

\section{Los amotinados en camino hacia Viena}

El 14 de abril los contingentes reales, siguiendo a los amotinados, quedaron sorprendidos porque los españoles salieron de Stompfa y construyeron un puente sobre el Morava, río fronterizo entre el Reino de Hungría, Austria y Bohemia, y abandonaron el territorio húngaro por la zona próxima a Marchegg. ${ }^{50} \mathrm{El}$ hecho de que los amotinados ya estuvieran en territorio de Austria y Moravia, a tan solo unas millas de Viena y amenazando así la corte real, aterrorizaba a los generales del ejército real.

\footnotetext{
46 Pálffy, A császárváros, 76.

${ }^{47}$ Sforza Pallavicin a Fernando I. Récse, 13 de abril de 1553. ibid, fol. 31.

48 Giovanni Baptista Castaldo a Fernando I. Posonio, 13 de abril de 1553. ibid, fol. 33-34.

${ }^{49}$ Giovanni Baptista Castaldo a Fernando I. Posonio, 14 de abril de 1553. ibid, fol. 37. Sforza Pallavicini a Fernando I. Posonio, 14 de abril de 1553. ibid, fol. 38.

${ }^{50}$ Luís de Osorio a Giovanni Baptista Castaldo. 14 de abril de 1553. ibid, fol. 36. La relación de Castaldo a Fernando I. Posonio, 14 de abril de 1553, ibid, fol. 35.
} 
La carta que Osorio dirigió a Castaldo refleja muy bien la sensación de falta de ideas: trasluce que Osorio no consideraba adecuada la fuerza bajo su mando para atacar a los amotinados y temía deber seguirlos incluso hasta otros territorios del Sacro Imperio. ${ }^{51}$ El mismo día Castaldo envió su carta a Fernando I rogándole que ordenara poner fuertes guardias en todos los caminos y puentes que conducían a Viena. Subrayó que él, junto con los capitanes hispanos Osorio y Francisco de Salamanca, harían todo lo posible para impedirles el cruce del Danubio. Pero la insolencia de los amotinados no tenía límites: Castaldo se quejaba de que incluso tuvieron el descaro de robar 8 caballos del conde Salm. A la vez, Osorio perseguía a los soldados con 200 caballos y otros infantes, mientras Salamanca con otros 200 a caballo y con infantes caminaba por la otra ribera del Danubio y les impedía el paso del rio. Mientras, Pallavicini formaba la retaguardia con el resto de soldados en caso de necesidad. ${ }^{52}$

Los hispanos habían saqueado la ciudad de Stomfa y sus alrededores antes de cruzar el rio Morava. Tenemos constancia de dos cartas escritas por estos al alcalde de Pozsonybeszterce (Záhorska Bistrica, Eslovaquia) conminándole a abastecerlos inmediatamente con 200 piezas de pan, 2 vacas, 4 becerros y 50 gallinas, bajo amenaza a la villa de sufrir "ciertas incomodidades". Otra carta con semejante contenido y tono fue despachada a Dévény-Újfalu (Devínska Nová Ves, Eslovaquia) demandando 250 panes, 4 vacas, 8 becerros y 60 gallinas. ${ }^{53}$

Mientras tanto, las negociaciones entre los "seditiosos hispanos" y los generales del ejército real no acabaron pese a los acontecimientos desfavorables para los primeros. En una carta fechada a 15 de abril los indignados soldados exponían al rey que, pese a que habían servido fielmente al soberano Fernando I desde hacía mucho tiempo (comienzos de 1549), eran atacados por las tropas reales después de haber salido de Transilvania. No recibían paga desde hacía más de catorce meses y el hambre y la miseria les afectaba cada día. Sus únicas exigencias eran que se mantuviesen a sí mismos. Se sentían ofendidos porque el capitán Osorio, compatriota, les impedía el paso por el Danubio en Pozsony e, incluso, ordenaba abrir fuego de artillería contra ellos. A la vez, suplicaban que Su Majestad tuviera la gracia de recibirlos para oír de su propia boca los agravios recibidos. Esa era la razón por la que se dirigieron a Viena, con la firme voluntad de servir a Su Majestad, tanto en ese momento como en el futuro. En cuanto a los saqueos, pues cometían actos de robo con violencia, eran debidos a que no habían recibido ni paga, ni abastecimiento alguno desde hace mucho tiempo. ${ }^{54}$

El mismo día, Pallavicini se dirigió con su ejército a Lassee (Austria); parecía que las constantes negociaciones con los sediciosos hispanos obtendrían resultados. Según la nueva carta de Pallavicini, Osorio, aún ansioso por pelear, se reunió nuevamente con los amotinados para mantener una nueva e infructuosa negociación. ${ }^{55}$ A la luz de otro fracaso de acuerdo, los contingentes reales intentaron cerrar todos los

${ }^{51}$ Luís de Osorio a Giovanni Baptista Castaldo. 14 de abril de 1553. ibid, fol. 36.

52 Sforza Pallavicini a Fernando I. Posonio, 14 de abril de 1553. ibid, fol. 39.

${ }^{53}$ Los españoles amotinados a los alcaldes de Beszterce. Stomfa, 12 y 14 de abril de 1553. ibid, fol. 92/b; Los españoles amotinados a los alcaldes de Újfalu. Stomfa, 112 de abril de 1553. ibid, sin número.

${ }^{54}$ Los españoles amotinados a los generales del ejército real. 15 de abril de 1553. ibid, fol. 40.

55 Sforza Pallavicini a Fernando I. Lassee, 15 de abril 1553. ibid, fol. 42. 
caminos que conducían de Marchegg a Viena e intentaron cercar a los españoles. En esos días, las fuerzas por ambas partes se concentraron en la vasta llanura de Morava. Las del rey estaban guarnicionadas en Lassee, mientras los amotinados el día 14 de abril estaban en Weikendorf (Austria) y al día siguiente en Enzensdorf (Austria). Las cartas de Pallavicini en estos días no ofrecen mucha información, pero lo que parece por estas cartas es que los amotinados llegaron a escapar del cerco dejando en ridículo a las tropas del rey para aparecer repentinamente en Wagram, a dos millas de Viena. La guarnición de Viena fue enviada urgentemente a Wagram con el refuerzo de unos cuantos cañones del arsenal. El conflicto estaba a punto de culminar. Los españoles reforzaron la iglesia de Wagram y tomaron posiciones de defensa en otros edificios cercanos. Las tropas reales concentraron sus fuerzas a media milla de Wagram en campo abierto. ${ }^{56}$

\section{Escaramuza y negociaciones cerca a Viena}

El 17 de abril la tropa de Pallavicini reforzada con la caballería ligera húngara, la guarnición de Viena y 4 falconetes, se dirigió a Aderklaa (Austria), aldea cercana a Wagram. Las partes se encontraron en el campo a medio camino entre las dos aldeas y negociaron por enésima vez. Los hispanos repitieron las mismas exigencias que ya habían sido rechazadas por el rey con anterioridad. De repente, comenzó una escaramuza entre los caballos húngaros y los amotinados, causando algunas muertes en ambos lados, en la que falleció uno de los líderes del motín. Los españoles se retiraron a la iglesia de Wagram. Pallavicini consideraba que su tropa era insuficiente para asediar la iglesia fortificada. Pidió que le enviaran de Viena cuatro cañones "murifragas" para batir las paredes de la iglesia mientras que cercaba Wagram para impedir la salida de los amotinados. ${ }^{57}$

Da la impresión de que las relaciones entre el Arsenal de Viena y Pallavicini no eran óptimas. El 17 de abril el italiano se quejó ante el Monarca de que los jefes del Gubernium de Austria Inferior y Bernhard Hammer, el del Arsenal de Viena, habían enviado dos bombardas en vez de los cuatro falconetes pedidos para batir la iglesia de Wagram. Uno de sus cañones fue enviado custodiado al Danubio junto con la guarnición de Viena para impedir el paso sobre el río. Pero Pallavicini no confiaba mucho en las aptitudes castrenses ni en el número de la infantería vienesa. Opinaba que únicamente eran capaces de encargarse de los cañones y guardarlos, pero no eran aptos para asediar a los amotinados. Incluso, corrían el riesgo de que los españoles veteranos capturasen los cañones sin dificultad si se les ordenaba defenderlos. ${ }^{58}$

Unas semanas después, ya acabada la crisis, el italiano tendría que dar explicaciones: tanto el Gobernador de Austria Inferior como el presidente del Arsenal de Viena acusaron a Pallavicini de que no les había informado a tiempo sobre los hechos de los españoles y de que su permisibilidad condujo a que los amotinados

\footnotetext{
56 Sforza Pallavicini a Fernando I. Raasdorf, 16 de abril 1553. ibid, Konv. A. fol. 51.

${ }^{57}$ Sforza Pallavicini a Fernando I. Aderklaa, 17 de abril de 1553. ibid, fol. 52.

58 Ibid, fol. 53.
} 
llegaran tan cerca de Viena. Según los argumentos de Pallavicini, los españoles caminaron hacia Viena en contra de sus claras órdenes y hubieran causado más daño si él no hubiera pedido más soldados y cañones. El Gubernium de Austria Inferior no cumplía con sus obligaciones y ni siquiera le enviaron el abastecimiento y munición necesarios. El italiano, al referirse a un conflicto de autorización, también comentó que era verdad que se había enfrentado con el presidente del Arsenal de Viena cuando él había asignado el lugar de guardia para los cañones, pero el presidente del Arsenal (Ministro di Armamentario di Viena como figura en la carta) modificó arbitrariamente las órdenes dadas por el italiano. Cuando, en presencia de otros soldados húngaros y alemanes, le interrogó, el consejero le respondió que llevaría a casa a los cañoneros enviados por el Gubernium. Eso hubiera causado que los cañones no protegidos hubieran caído en manos de los españoles. Para evitar este peligro e impedir el menoscabo de su reputación, el italiano castigó al consejero. ${ }^{59}$

Pese a las quejas de Pallavicini respecto a la calidad de su ejército, parece que las tropas reales en Wagram, reforzadas con la infantería de Viena, eran sobradas para obstaculizar el paso de los hispanos amotinados. Los españoles tampoco querían entrar en mayores escaramuzas frente al ejército del rey. Mientras fortalecían la iglesia de Wagram, los del bando real les cercaban y cortaban los abastecimientos para evitar el "derrame de sangre cristiana". Pallavicini expuso claramente que no podía asediar Wagram a pesar de sus fuerzas y los cañones sin mucha pérdida de sangre. Por eso el italiano esperaba la rendición de los españoles. El asedio - comentaba Pallavicini a Fernando I - causaría mucha pérdida tanto en dinero, como en tiempo y vidas humanas, sin contar los daños que causaría a los vecinos de Wagram. ${ }^{60}$ En aquellos días, incluso la cohesión de los amotinados empezaba a quebrarse. De hecho, algunos volvieron al servicio real, abandonando el campo de Wagram. El 17 de abril Castaldo informó a Fernando I que le enviaron unos treinta de los que habían vuelto al servicio del rey. Opinó también que sería inevitable condenar a un número tres veces mayor de los soldados. ${ }^{61}$

El 18 de abril los españoles acudieron a Fernando I, rogándole humildemente que, por respeto a sus largos servicios prestados, el monarca tuviera el favor de concederles gracia real. Incluso declararon que aceptarían las enmiendas a sus condiciones, solicitando a Fernando I que él también mostrara flexibilidad aceptando algunas, de manera que se compensarían muchas injusticias cometidas. A la vista de estos progresos, Pallacivini encargó a Luis de Osorio pagar cierta parte de la paga retrasada y pidió que se entregaran 2.000 táleros (monedas de plata) al capitán para distribuirlos entre los soldados. Se planeaba que los amotinados fueran revistados en una muestra general, día en el que recibirían también el resto de su paga atrasada. El italiano también pidió que se devolvieran las banderas a los soldados y que aquellos

\footnotetext{
${ }^{59}$ Sforza Pallavicini a Fernando I. Győr, 28 de abril de 1553. ibid, fol. 68.

${ }^{60}$ Sforza Pallavicini a Fernando I. Aderklaa, 18 de abril de 1553. ibid fol. 128-129.

${ }^{61}$ Giovanni Baptista Castaldo a Fernando I. 17 de abril de 1553. ibid, fol. 44.
} 
obedientes que hubieran vuelto al servicio se les guarnicionara en el condado de Sopron o en el castillo de Pápa, ambos en Hungría. ${ }^{62}$

\section{Gracia real, juramento de los amotinados y disolución del primer tercio viejo de Nápoles}

Por fin, el 19 de abril ambas partes llegaron a un acuerdo. Fernando I les concedió una gracia real fechada en Wiener Neustadt (Austria). Aunque el monarca declaró que, pese a que los hispanos amotinados le habían causado enorme desprestigio y daño y por esa razón tendría el derecho de condenarles sin remordimiento alguno, les ofrecía tal perdón. Pero las banderas no serían devueltas a los soldados, sino que las entregaba a Sforza Pallavicini para que las guardase hasta la muestra que tendría lugar. Luis de Osorio recibió los 2.000 táleros para pagar a los soldados beneficiados por la gracia real. Según la promesa del rey, el resto de la paga les sería entregada en la muestra. Los españoles serían guarnicionados y abastecidos en Pápa y la muestra también se organizaría allí. Las decisiones fueron despachadas a los soldados en una carta en español, firmada por el rey. El monarca, en su carta a Pallavicini, alababa aparte a los capitanes Luis de Osorio y Francisco de Salamanca. El borrador de la carta que hoy se halla en el Archivo de Viena incluye una frase cruzada según la cual los dos capitanes habrían recibido el título de consejero real. No disponemos de información sobre si finalmente se les concedió o no ${ }^{63}$ En cuanto a Luis de Osorio, merece la pena mencionar que en la expedición de Gian Andrea Doria contra Gelves (Djerba, Túnez) en 1560 participó un maestre de campo con tal nombre. Deduzco que el capitán Osorio habría promocionado gracias a su servicio en Hungría y, junto con otros oficiales que habían luchado en Hungría (Bernardo de Aldana, Álvaro de Sande), seguiría combatiendo a los otomanos por el Mediterráneo ya con el empleo de maestre de campo.

Los amotinados prestaron nuevo juramento el 23 de abril mientras el capitán Osorio guardaba las banderas hasta la muestra general. El ejército real volvió a sus guarniciones, tanto en Győr como en Viena. Los españoles se dirigieron a Pápa. ${ }^{64}$ En un estudio reciente del historiador Géza Pálffy se halla que los servidores de origen español de Fernando I, Hans von Hoyos (=Juan de Hoyos) y Diego de Alba, habían sido encargados de negociar con los españoles amotinados. Probablemente estos dos serían los representantes reales que hicieron "generalis lustratio" sobre los españoles guarnicionados en el castillo de Pápa (Hungría). ${ }^{65}$ No tenemos constancia de hasta cuándo permanecieron los miembros del tercio de Aldana en Hungría. En los Reichsregisterbücher de los años 1553-1554 que se hallan actualmente en el Haus-, Hofund Staatsarchiv de Austria encontramos un gran número de salvoconductos otorgados a personas españolas para abandonar el país y volver a la Monarquía Católica

\footnotetext{
62 Sforza Pallavicini a Fernando I. Aderklaa, 18 de abril de 1553. ibid, fol. 128-129.

${ }^{63}$ Fernando I a Sforza Pallavicini. Wiener Neustadt, 19 de abril de 1553. ibid, fol. 133.

${ }^{64}$ Sforza Pallavicini, Aderklaa, 23 de abril de 1553. ibid fol. 143.

${ }^{65}$ Géza Pálffy y Richard Perger, “A magyarországi török háborúk résztvevőinek síremlékei Bécsben (XVI-XVII. század.)”, Fons 5 (1998): 224.
} 
con licencia. Como muchos de ellos habían sido mencionados tanto por el libro de la expedición de Aldana como en la correspondencia del mismo maestre de campo (p. ej. Diego de Aguirre, Luis de Barrientos, Luis Vélez de Mendoza etc.), es muy probable que esas personas fueran los soldados supervivientes de las luchas de 1549-1553 y buena parte se encontrara entre los 400 españoles amotinados. ${ }^{66} \mathrm{El}$ gran número de los passuales nos indica que la mayoría de ellos habrían abandonado el país magiar con permiso real durante 1553-1554. Mientras, el maestre de campo Aldana solo salió de su celda en la cárcel de Trencsén después de la intervención de la corte española de Felipe II (1556-1598), tal como muestro en las siguientes líneas.

Finalmente, tenemos que subrayar que parece que el tercio de Nápoles encabezado por el maestre de campo Bernardo Villela de Aldana prácticamente se había desintegrado y disuelto durante las luchas en Hungría (1549-1553). Los sucesos del motín de los 400 supervivientes de las guerras era el episodio de clausura del primer tercio viejo de Nápoles. La administración militar de Carlos V crearía otro tercio viejo de Nápoles, homónimo al de Aldana. A la vez, no tenemos constancia de que ningún otro tercio viejo hubiera sufrido fin semejante y sido reorganizado. ${ }^{67}$

\section{LA SUERTE DE BERNARDO DE ALDANA DESDE SU ENCARCELAMIENTO EN TRENCSÉN HASTA SU MUERTE}

Después de haber conocido el motín del tercio de Aldana quisiera recapitular la suerte del maestre de campo Bernardo de Aldana después de la expedición en Hungría. En la historiografía húngara tiene una pésima imagen, oscurecida por su enemigo Giovanni Baptista Castaldo, maestre de campo general de las tropas reales en Hungría entre 1552 y 1553 . La enemistad entre los dos databa de la guerra de Esmalcalda de 1547, un hecho que también figura en la Expedición. ${ }^{68}$ El mismo Aldana, con su conducta durante la batalla campal de Szeged y durante los acontecimientos de Lippa, por los cuales fue encarcelado, dio motivos para mantener la fama de mercenario sin talento, vil y de mala voluntad. Pero su actividad en 1549 y 1550 durante la expedición por Hungría Superior contra los señores de los castillos de Szitnya, Csábrág, Murány, mas luego su participación en la construcción del castillo de Szolnok en 1550, evidenciaron que el maestre de campo era un experto ingeniero militar maestro en el arte de asediar y defender plazas fuertes. Incluso, los paralelismos que se observan en

${ }^{66}$ HHStA, Reichsregisterbücher volúmenes 11-13 y 30-31. Incluyen los passuales de unos 70-80 soldados españoles.

${ }^{67}$ Jesús Martínez de Merlo, "La organización de los ejércitos en los Austrias", Revista de Historia Militar I extraordinario (2017): 154, 174. Martínez de Merlo en la página 174 confunde el maestre de campo Bernardo de Aldana con Pedro Vivas.

${ }^{68} \mathrm{El}$ autor anónimo de la Expedición mencionó que Castaldo había considerado como gran ofensa a su reputación que, durante la Guerra de Esmalcalda, tras haber escogido el lugar para que acampara el ejército, en una ocasión el emperador Carlos $\mathrm{V}$, en vez de aceptar sus consejos escuchó los de Aldana, quien era por aquel entonces capitán, inferior al maestre de campo Castaldo. 
la construcción de los castillos de Szolnok y Djerba (Gelves) en 1560 y su papel en la fortificación de ambos sitios resaltaban su talento. ${ }^{69}$

\section{Excarcelación de Bernardo de Aldana y sus encargos en Italia}

Pero vayamos por partes: El 16 de junio de 1554 Aldana, acusado de lesa majestad por el abandono del castillo de Lippa, fue condenado a muerte y encarcelado en el castillo de Trencsén, después de un largo pleito de un año. ${ }^{70}$ Durante su encarcelamiento su vida dio giros sorprendentes: el mismo duque de Alba comentó el 18 de octubre de 1555 que, tras de la muerte de don Ramón de Cardona, capitán general de la artillería de Milanesado, no había otra persona más oportuna que el maestre de campo Bernardo de Aldana para ocupar su puesto. Por esa razón solicitó ante Felipe II que interviniera ante Fernando I para concederle la libertad a Aldana y tal puesto. ${ }^{71}$ Parece evidente que la intervención de una figura de tanto peso y reputación como el duque de Alba contribuyó en gran medida a la liberación de Aldana y a su nombramiento. La petición de duque de Alba fue escuchada y los embajadores de Felipe II, Luis Venegas de Figueroa y Pedro Laso de Castilla intercedieron por él en Viena, siendo entonces liberado Aldana tras la celebración de las cortes húngaras en Pozsony, en enero de $1556 .{ }^{72} \mathrm{El}$ maestre de campo fue nombrado capitán general de la artillería del Milanesado por un periodo de uno o dos años. En el invierno de 1558-1559 el rey Felipe II le encargó evaluar el estado de los castillos y puertos del Reino de Nápoles así como la capacidad militar del Regno. ${ }^{73}$ Después de realizar la

\footnotetext{
${ }^{69}$ Véase: Korpás, "Egy spanyol”, passim.

70 Pálffy, "Várfeladók", 216-217. La carta del juicio de Aldana fechada a 16 de junio de 1554 se halla en Történeti Lapok, 2 de marzo de 1875, vol. II. núm. 51: 801-802.

${ }^{71}$ Relación del duque de Alba. 18 de octubre de 1555. AGS, Estado, Milán, leg. 1208, fol. 9.: “...Que a Cesaro de Nápoles encomendó el cargo de la artilleria que esta vaco por fallecimiento de don Ramón de Cardona y, no hallando para él persona más conveniente que la del maestre de campo Aldana, supplica se scrivia a los reyes de Romanos y Bohemia para que le den libertad..."

${ }^{72}$ Felipe II a Fernando I. Hampton Court, 18 de julio de 1555. RAH, Colección de Salazar y Castro A-52. fol. 6: "Quanto holgará [a Felipe II] que Vuestra Majestad mandase dar libertad al maestre de campo Bernardino de Aldaña... y parecerme que, con haver estado en prisión tres años, había purgado vastamente la culpa si alguna tubo...”. La respuesta de Fernando I a Felipe II. Viena, 7 de enero de 1556. RAH, Salazar y Castro, A-52, fol. 11: "Por una carta que al licenciado Gamiz mandé escrivir desde Posonio y por las que había escrito Luis Venegas y dicho después de su boca a Vuestra Alteza, había entendido la libertad del maestre de campo Bernardo de Aldana, llevador desta y los honestos y buenos respectos por los quales se dirigió hasta la celebración de la dieta de Hvngría que en aquella ciudad tuve... y, haviendo de ir el dicho maestre de campo a presentarse a Vuestra Alteza y besarle las manos, como debe, por el favor y merced que para esta su livertad le ha hecho Vuestra Alteza, le haga o carga de los de su profesión en que Vuestra Alteza lo mande emplear..."

${ }^{73}$ Carta del cardenal de la Cueva (Bartolomé de la Cueva y Toledo) a Felipe II. 26 de agosto de 1559. AGS, Estado, Nápoles, leg. 1049, fol. 91: "Por una relación que me ha enbiado el maestre de campo Aldana, que ha escrito particularmente de la manera que están las tierras maritimas y otras de la frontera desse reyno [de Nápoles], por lo que entendemos que importa a su seguridad y defensa, poner en ellas todo buen recaudo y con brevedad, tanto mas agora, con la nueva que se tiene de que los franceses han pedido el armada al turco para que venga este verano...".
} 
inspección, presentó su relación detallada sobre la capacidad defensiva del castillo de Bríndisi y de su puerto al igual que el peligro que implicaban los otomanos desde el puerto de Velona (hoy Vlorë, Albania), muy cerca de Italia. Incluyó también el estado de la ciudad de Tarento, dando una descripción detallada sobre el castillo, las posibilidades de fortalecerlo e incluso comentó que los territorios entre Otranto y Bari eran muy vulnerables. Consideró además que, en caso de que se destruyeran los cinco pequeños castillos en la región, se correría el riesgo de que esa zona quedara deshabitada. Aldana llamó asimismo la atención sobre los problemas defensivos de Manfredonia, Barleta e incluso los de Pescara, Gaeta, Nola y Capua. ${ }^{74}$

Durante el verano de 1559, Aldana fue nombrado por Felipe II capitán general de artillería del Reino de Nápoles. ${ }^{75}$ Su nuevo cargo tenía mucho que ver con la expedición contra Gelves, planeada para $1560 .{ }^{76}$ En este ataque Aldana ostentó el cargo de capitán general de la artillería de la Armada y, en concordancia con su rango, embarcó en la galera real junto con los otros generales de la expedición. ${ }^{77}$ Un empleo de tal calibre solo se le habría asignado a oficiales de la mayor calidad. Los cargos de Aldana, tanto en el Milanesado como en Nápoles o ahora con la expedición marítima, confirman que, pese a su mala fama divulgada en Hungría, era un militar experto y preparado.

Es un detalle curioso que durante los preparativos Aldana supuestamente se encontró personalmente con don Álvaro de Sande, el otro maestre de campo español que había conducido el tercio viejo de Lombardía (de 2.500 soldados) a Hungría en 1545, luchando al servicio de Fernando I contra el oligarca húngaro János Podmaniczky. ${ }^{78}$

\footnotetext{
${ }^{74}$ Relación de Bernardo de Aldana sobre el estado de la defensa del Reino de Nápoles. Nápoles, 1 de enero de 1559. AGS, Estado Nápoles, leg. 1049, fol. 95. La opinión del virrey cardenal de la Cueva: Nápoles, 26 de agosto de 1559. AGS, Estado Nápoles, leg. 1049, fol. 91. Opinión del duque de Alba sobre la relación de Aldana: Cateau Cambresis, 8 de febrero de 1559. AGS, Estado Nápoles, leg. 1049, fol. 94.

${ }^{75}$ Aldana a Felipe II. Nápoles, 18 de septiembre. AGS, Estado, Nápoles, leg. 1049, fol. 149, 150: “S. C. R. Magestad. Venido que fue el duque de Alcala le informe de todas las fortificaciones y fabricas deste reyno como Vuestra Majestad me mando por su carta y se lo di por memoria, a la mesma sazon llego el titulo de mi cargo de la artilleria deste reyno y presentelo al virrey...".

${ }^{76}$ Sobre la expedición de Gelves véase: Guilmartin, John Francis Jr., Gunpowder and Galleys. Changing technology and Mediterranean warfare at sea in the Sixteenth Century (London: Cambridge University Press, 1974), 95-123; Ricardo Cerezo Martínez, Las armadas de Felipe II (Madrid: Editorial San Martín, 1988), 195-200. También la crónica de Pedro Barrantes de Maldonado sobre la expedición de Gelves en Colección de libros españoles raros o curiosos. Tres relaciones históricas (Madrid, 1889), t. XIX, 207-209.

${ }^{77}$ Sobre los oficios de Aldana, carta del virrey de Nápoles al maestre de campo Álvaro de Sande respecto a lo que debe tratar con el virrey de Sicilia. Nápoles, 1559. AGS, Estado Nápoles, leg. 1042, fol. 164. En cuanto a las personas que caían en cautiverio en la galera real, incluyendo el nombre de Aldana, véase la carta de Fernando de Zapata al virrey de Nápoles. Messina, 19 de mayo de 1560. AGS, Estado Sicilia. leg. 1125, fol. 52.

${ }^{78}$ El mandamiento del virrey de Nápoles a Álvaro de Sande sobre lo que tenía que tratar con el virrey de Sicilia. Nápoles, 1559. AGS, Estado Nápoles, leg. 1042, fol 164: “... A Bernardo de Aldana hablare para que vaya a tener cargo de artillería en aquella empresa; que dare aviso a su Señoría de la resolución que tomare...". Sobre la expedición de Álvaro de Sande en Hungría en 1545 véase: Zoltán Korpás, “La expedición de Álvaro de Sande a Hungría Superior, 1545”, en Palabras enlazadas. Estudios en
} 
La correspondencia da la impresión de que Aldana no tenía muchas ganas de tomar parte en esta nueva lucha contra los otomanos. Quizás tuviera malos presentimientos:

...llegado que fue aquí a Nápoles me a mandado que me ponga en horden para yr en la jornada de Trípoli, porque el duque de Medina se lo a embiado a rogar con mucha instancia y a mí, assi mesmo, me lo ha escrito y embiado a encargar con don Sancho de Leyva. Yo, Señor, no estimo cosa más que cuando puedo emplear mi persona en el servicio de Vuestra Magestad, pero querría açertarme que fuesse con su satisfacción. Y también no querría haber falta en cossa que tocasse a la reparación y defensión deste reino, pues Vuestra Magestad me a destinado para que le sirva en él y, por este respecto, me a atrevido supplicar por esta vía a Vuestra Magestad me haga merced significarme su voluntad en este caso, para que, siendo que yo vaya, lo haga con más satisfación mía y, si no, lo es que yo no caya (sic!) en falta en lo que toca al serviçio de Vuestra Majestad. ${ }^{79}$

\section{Expedición de Gelves - muerte de Aldana}

Pero echemos un vistazo a la expedición de 1560 contra Trípoli, fracasada frente a la isla de Gelves (Djerba). Queda claro que el nuevo cargo de Aldana estaba en estrecha relación con la expedición planeada. La armada cristiana se concentró en Mesina, levando anclas hacia Trípoli el 10 de febrero de 1560. A causa de la falta de agua, la armada viró hacia Gelves, desembarcando en la isla. A no tardar comenzaron a construir una fortaleza nueva y el papel de Aldana se valora en esas circunstancias. Como capitán general de la artillería era miembro del consejo de guerra encabezado por el almirante Gian Andrea Doria, junto con otros oficiales de notoria reputación tales como Sancho de Leyva, capitán general de las galeras de Nápoles, Berenguer de Requesens, capitán general de las galeras de Sicilia, Andrea Gonzaga, capitán general de las naos, e, incluso, los maestres de campo Álvaro de Sande y Luis Osorio, conocidos personalmente por Aldana. En este punto, podemos suponer que Luis Osorio sea la misma persona que había servido como capitán en el tercio de Aldana en Hungría y sofocado el motín de los españoles junto con Sforza Pallavicini y otros al servicio de Fernando I.

No cabe dentro de los marcos de este estudio detallar la expedición de Gelves, pero merece la pena subrayar que el ejército cristiano la había ocupado sin resistencia y durante marzo habían empezado la construcción de una nueva fortaleza, pensando que la armada otomana tardaría meses en llegar. Se suponía que para aquel entonces la isla ya estaría fortalecida y el ataque contra Trípoli sería fácil de ejecutar. Pero, pese a las expectaciones, las galeras de Piali cruzaron el Mediterráneo oriental en tan solo veinte días y el 11 de mayo ya estaban en las cercanías de Gelves. Sorprendió a la

homenaje al profesor Lásæló Scholz, eds. Zsuzsanna Bárkányi y Margit Santosné Blastik, (Szeged: JATE Press, 2018), 217-229.

${ }^{79}$ Aldana a Felipe II. Nápoles, 29 de julio de 1559. AGS, Estado Nápoles, leg. 1049. fol. 251. 
armada cristiana, que fue destruida en tan solo unas horas. Luego los otomanos desembarcaron en la isla, asediando la fortaleza recién construida. ${ }^{80}$

El pachá de Túnez, Turgut Reis (o Dragut) se unió a los de Piali y ambas fuerzas forzaron la rendición del castillo de Gelves tras dos meses de asedio. El capitán del castillo, Álvaro de Sande, quien gozaba de buena reputación, era conocido tanto en España como en Hungría gracias a su expedición en 1545 en Hungría Superior. En 1565 encabezó junto con Ascanio della Corgna la infantería española desembarcada en la isla de Malta para librarla del asedio otomano. También ha de mencionarse su cargo como Gobernador de Milán, donde uno de sus soldados fue el mismo Cervantes. Durante la expedición de Gelves cayeron cautivos hombres de mucho valor, como Berenguer Requesens, Sancho de Leyva, Fadrique de Cardona, el obispo de Mallorca e, incluso, Bernardo de Aldana y más tarde el defensor del castillo, Álvaro de Sande. ${ }^{81}$ Una carta de 16 de mayo nos revela que Aldana estaba en la galera real y fue capturado con todos los supervivientes que lucharon en aquel barco. Unos días después otra carta nos describe a Aldana, sin identificarlo por su nombre sino como maestre de campo "de poca persona con la barba roxa" ${ }^{2}$. Parte de los cautivos fueron llevados a Túnez, entre ellos Aldana, otros junto con Álvaro de Sande a Estambul. Entre los cautivos de la Sublime Puerta hayamos a un alférez llamado Andrés de Ruiseco. Merece la pena presentarle, pues en Simancas se halla una carta de él, enviada al residente del Emperador en Estambul para pedir el apoyo de Felipe II para su rescate. Argumentó que había servido veinticuatro años tanto a Felipe II como a su padre Carlos V en cargos de alférez y sargento mayor en diferentes campañas. Entre ellas, en 1545 luchó en la compañía del capitán Navarrete en el tercio de Álvaro de Sande, sirviendo a Fernando I durante la expedición contra los magnates húngaros en el condado de Trencsén (Hungría Superior, Eslovaquia actual). Luego volvió a Hungría en la compañía de Pedro de Ávila en el tercio de Bernardo de Aldana, luchando en el asedio de Murány, a orillas del rio Tisza en la construcción del castillo de Szolnok y contra los otomanos durante el primer asedio de Temesvár (1551), además de ser parte del contingente que abandonó el castillo de Lippa que causó el encarcelamiento de Aldana. Incluso refirió estar entre los cuatrocientos españoles amotinados en 1553. Finalmente cayó en cautiverio otomano durante la campaña de Gelves. Sabemos por él que una compañía del tercio de Álvaro de Sande fue otorgada a Bernardo de Aldana después de la batalla de Mühlberg para ser llevada a Hungría de nuevo; Ruiseco es el único de

${ }^{80}$ Guilmartin, Gunpowder, 95-123; Cerezo Martínez, Las Armadas, 195-200; Barrantes de Maldonado, Tres relaciones, 207-209.

${ }^{81}$ Fernando de Zapata al virrey de Nápoles. Messina, 19 de mayo de 1560. AGS, Estado Sicilia. Leg. 1125, fol. 52: “ ... eran todos perdidos que yvan en la Capitana con el virrey don Sancho el señor don Fadrique de Cardona, el obispo de Mallorca, el maestre de campo Aldana y muchos otros cavalleros...”.

82 "Lo que se entiende en Trapana a los 9 de junio por una fragata venida de Gelves, que partio del fuerte a los 28 de mayo de 1560". AGS, Estado Sicilia, leg. 1125, fol. 59: "hablo sobre las dichas galeras con el obispo de Mallorca el qual estava bueno y con don Fadrique de Cardona que estava malo y otro maestre de campo español que no sabe como se llama pero que era de poca persona con la barba roxa y que estos quedavan en Tripol con Dragut". 
los 150-200 españoles que pasaron dos veces por Hungría y a quien conocemos de nombre. $^{83}$

\section{Paralelismos en la fortificación de Gelves y de Szolnok - papel de Aldana}

Pero volvamos a Aldana: después del desembarco en Gelves de las fuerzas cristianas en marzo, Aldana preparó, junto con el ingeniero Antonio de Conde y el maestre de campo Sancho de Leyva, el diseño de un castillo con cuatro bastiones, circunvalando un castillo antiguo y con demasiado espacio para mayor número de defensores. Este plan era chocantemente similar a lo realizado por él durante la construcción del castillo de Szolnok precisamente diez años antes, en otoño de 1550. Los dos mil soldados de la Armada fueron despachados a diferentes tareas: los alemanes se ocupaban de las trincheras, los de Malta construyeron un bastión, los italianos y los españoles fueron responsables de otros dos bastiones, mientras los remeros y marineros se encargaron del cuarto. El castillo antiguo fue destruido parcialmente por los alemanes y también construyeron una cisterna para el abastecimiento de agua y plataformas para la artillería. Según las fuentes parece que durante la construcción Aldana permaneció más en la isla que en los barcos y controló activamente el progreso de edificación. Quizá a ello se deba que según unos autores Aldana cayera preso no durante la corta batalla marítima sino durante el asedio. Pero tenemos constancia de que para la rendición del castillo de Gelves ya no estaba en la isla y supuestamente falleció en junio de 1560 a consecuencia de sus heridas. En cuanto a sus últimos días la mejor fuente es la correspondencia de su mujer, Beatriz de Tovar. ${ }^{84}$ El 25 de junio la señora Tovar escribió una carta desesperada para rescatarlo,

${ }^{83}$ Carta de Andrés de Ruiseco al residente de los Austria ante la Sublime Puerta en Estambul. Estado Alemania, leg. 650, s.d.: “...Al Rey de Spaña me es muy grande obligacion por aver servido 24 años a su padre y a El he le servido de sargento de alferez y de sargento mayor en presencia de los dos, asy mesmo servido... [sérülés] del emperador don Fernando en tiempo de don Alvaro de Sande contra el Copoca y Pomani y estuve en todo lo demas que ally se offrecio hasta que venimos alla de Alemania en la compania de Navarrete despues bolvi otra vez a servir a su Magestad en Hungria con las siete companias que llevo el maestre de campo Aldana, en la compania de Pedro de Avila y fuymos a tomar los castillos en Moran. Estuve asy mesmo en la fortificacion del fuerte que hizieron en la Tiza que despues fue muerto por los Turcos y me halle en todo lo de Transsilvania en lo de Temezvar y Lippa con Juan Baptista Castaldo general y con el mismo Aldana y con el Beheck y el Balasary y Losonzick que despues fue muerto por los turcos. Deveme la Magestad del Emperador desta jornada más de 150 ducados y estos por el motin que huvo entre los spañoles..."

${ }^{84}$ La mujer de Aldana, Beatriz de Tovar a Felipe II. 25 de junio 1560. AGS, Estado Nápoles. Leg. 1050.11. fol. 80.: "Pues le consta ya la prision del maestre de campo Aldana, mi marido no ay para que yo trate della sino de la muy crecida angustia y desconsuelo en que me tiene considerando ser en poder de turcos y los trabajos con que su inhumanidad aflixe qualquiera genero de persona christiana que a sus manos viene y como esta memoria acreciente todas oras mi dolor y la tribulacion que me causa buscandole remedio y sabiendo aver venido en mano de Draguty estar en Tripol con esperança que lo queran rescatar y como en esta vida no ay cosa que mas desee ni deva procurar he travajado quanto me ha sido posible poner en Ceçilia, Malta y la Goleta un credito de cinço mill ducados para este effecto y aviendo hecho instancia con el duque de Alcala que por contemplacion de los servicios de mi marido tuviese por bien de mandar que la corte me le diese aquella de las mercedes que goza de Vuestra Majestad...". 
explicándole al monarca que para salvar a su marido pidió un préstamo de un valor increíblemente alto, cinco mil ducados. ${ }^{85}$ Mientras, el 14 de junio el virrey de Nápoles informó a Felipe II de que parecía ser posible el rescate de Leyva, Requesens, Cardona y Aldana, para lo que pedía el rápido consentimiento del rey. ${ }^{86}$ Pero a lo largo de junio Aldana falleció en Trípoli y uno de sus oficiales, Juan de Bolaños, escribió al rey que antes de su muerte el maestre de campo había declarado su testamento para que sus bienes de la tenencia de Sedella (en Málaga) fueran heredados por Gaspar de Mercado, hijo de su hermano. ${ }^{87}$

Como constatamos, durante la primavera de 1560 Aldana estaba en una situación personal sorprendentemente similar a la que había padecido en Hungría en 1550, en el castillo de Szolnok: en ambos casos, los cristianos ocuparon un castillo de posición estratégica, sin defensores y en tierra de nadie, cerca de intereses otomanos (Trípoli en caso de Gelves y Transilvania y sur de Hungría en caso de Szolnok). En ambas ocasiones no se hizo esperar una reacción rápida y enérgica de los otomanos, con lo que los cristianos solo dispusieron de unos pocos meses para reforzar el sitio. A la vez, en ambos casos, los planes y diseños de Aldana tenían un papel sobresaliente e, incluso, se parecían uno al otro (cuatro bastiones de piedra en el caso de Gelves y otros tantos de barro en el caso de Szolnok, por falta de piedra.) Tanto su actividad en Szolnok como en Gelves, mostrando su maestría en el campo de la ingeniería militar, arroja nuevas luces sobre su desafío y fracaso durante la defensa de Lippa, donde fue acusado de lesa de majestad por abandonar el castillo. Como subraya el libro sobre la expedición de Aldana en Hungría, a lo mejor no le faltaba razón a Aldana cuando afirmaba que el castillo de Lippa, tras haber sufrido el tercer asedio en apenas un año, ni siquiera estaba en condiciones para poder ser protegido.

${ }^{85}$ Servirá como punto de referencia que sabemos por una carta anterior de Aldana a Felipe II que su sueldo mensual como capitán general de artillería de Nápoles era de setenta ducados. Véase: Bernardo de Aldana a Felipe II. Nápoles, 18 de septiembre de 1559. AGS, Estado Nápoles, leg. 1049, fol. 149.

${ }^{86}$ El virrey de Nápoles a Felipe II. Nápoles, 14 de junio de 1560. AGS, Estado Nápoles. Leg. 1050. fol. 93.

${ }^{87}$ Juan de Bolaños a Felipe II. Nápoles, 7 de septiembre de 1560. AGS, Estado Nápoles, leg. 1050, fol. 127. Sobre la tenencia de Aldana en Sedella de valor de 100.000 maravedíes véase: Korpás, "Egy spanyol”, 16. La tenencia fue otorgada por Carlos V en Augsburgo el 18 de febrero de 1548. El documento se halla en AGS, Contaduría Mayor de Sueldos, Segunda serie. Tenencias de Fortalezas. Leg. 376. Sedella. 


\section{ANEXO I}
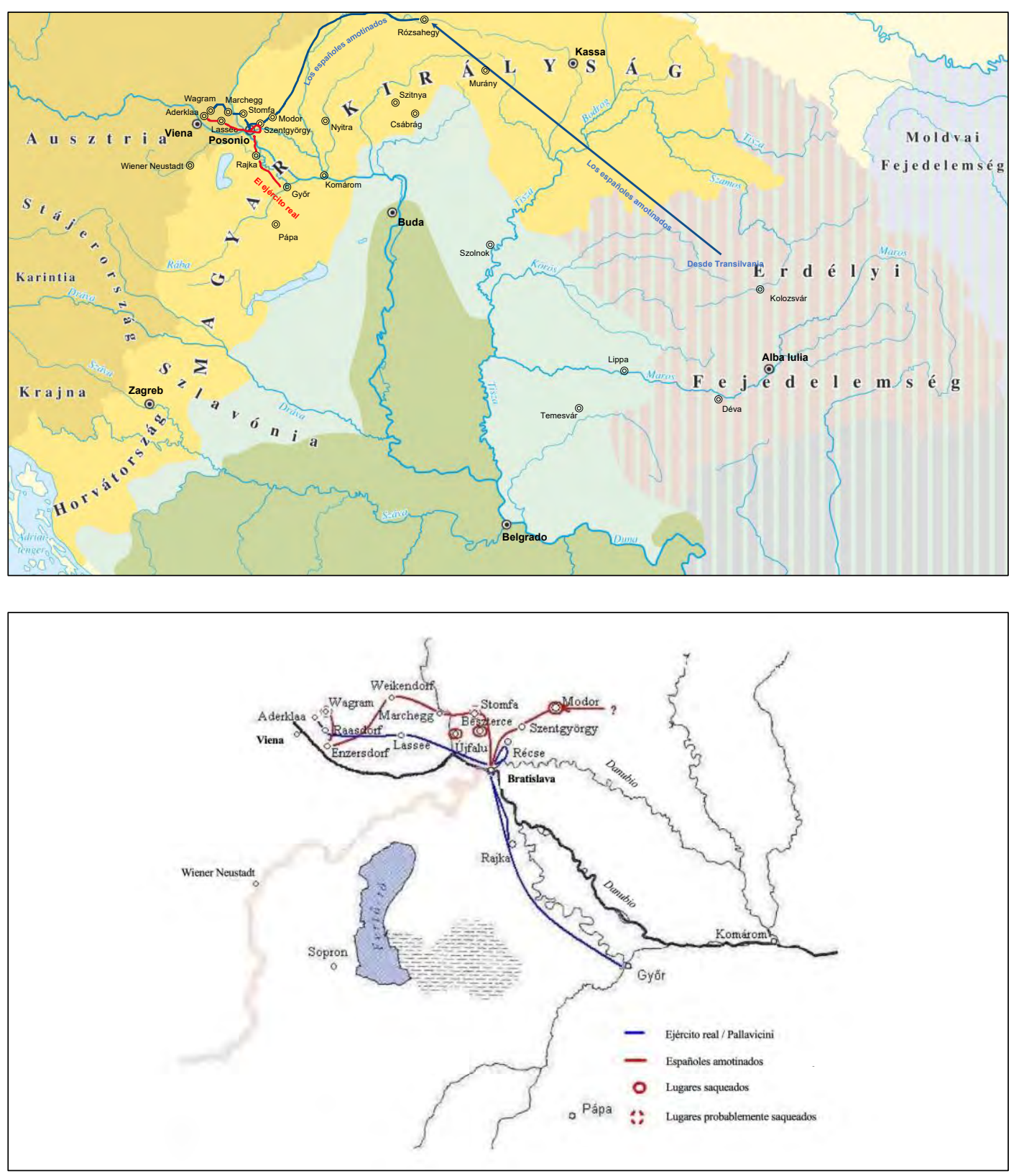

Fig. 1. Los movimientos del ejército real y de los amotinados entre el 24 de marzo y el 19 abril de 1553. 


\section{REFERENCIAS BIBLIOGRÁFICAS}

\section{Fuentes publicadas}

Barabás, Samu. "Erdély történetére vonatkozó regesták 1551-1553”, en Történelmi Tár 14-15 (1891-1892), en 6 entregas.

Bethlen, Farkas. Erdély története (Budapest - Kolozsvár: Enciklopédia Kiadó, 2002), vol. II. (=Wolfgang Bethlen: Historia de rebus Transsylvanicis [Cibinium, 1782])

Centorio, Ascanio. Commentarii della guerra di Transilvania (Venecia: 1566).

Escribano Martín, Francisco, ed. La expedición del maestre de campo Bernardo de Aldana a Hungría en 1548 (Madrid: Ed. Miraguano, 2010).

Korpás, Zoltán. "Egy spanyol zsoldosvezér levelei a XVI. század közepén vívott magyarországi háborúkról. Adalékok Bernardo de Aldana magyarországi tevékenységéhez (1548-1552)", en Fons 1-2 (1999): 3-129.

Rodríguez Villa, Antonio, ed. Expedición del maestre de campo Bernardo de Aldana à Hungría en 1548 (Madrid: Ed. Medina, 1878).

Rozanski, Feliks, ed. Wyprawa na Wegry Bernarda Aldany jenerała kawaleryi hiszpańskiej w latach 1548-1556 (Krakow: Redakcja "Przeglądu Polskiego", 1882).

Szakály, Ferenc, ed. Bernardo de Aldana magyarországi hadjárata [1548-1552] (Budapest: Európa Könyvkiadó, 1986).

\section{Bibliografía}

Almási, Gábor; Teszelszky, Kees; Zarnóczki, Áron; Brzeziński, Szymon; Horn, Ildikó eds. A Divided Hungary in Europe. Exchanges, Networks and Representations, 1541 1699 (Newcastle upon Tyne: Cambridge Scholars, 2014).

Barrantes de Maldonado, Pedro. Colección de libros españoles raros o curiosos. Tres relaciones históricas (Madrid: 1889), t. XIX.

Cerezo Martínez, Ricardo. Las armadas de Felipe II (Madrid: Editorial San Martín, 1988).

Guilmartin, John Francis Jr. Gunpowder and Galleys. Changing technology and Mediterranean warfare at sea in the Sixteenth Century (London: Cambridge University Press, 1974). 
Guitman, Barnabás; Korpás, Zoltán; Tóth, Ferenc; B. Szabó, János. “A magyarországi török várháborúk nemzetközi háttere, 1547-1556 (= The International Background of the Ottoman War in Hungary, 1547-1556)", Világtörténet 9:2 (2019): 253-293.

Kenyeres, István. “A magyarországi végvárak és a mezei hadak élelmezési szervezetének archontológiája a XVI. században”, Fons 2 (2004): 329-395.

Kertész, Róbert; Korpás, Zoltán. “A szolnoki végvár felépítése 1550-1552-ben és Bernardo Villela de Aldana ide kapcsolódó levelei”, TISICUM, Szolnok, 22 (2013): 387-450.

Korpás, Zoltán. "La correspondencia de un soldado español de las guerras de Hungría a mediados del siglo XVI. Comentarios al diario de Bernardo de Aldana (15481552)", Hispania 206 (2000): 881-910.

Korpás, Zoltán. "Las luchas antiturcas en Hungría y la política oriental de los Austrias 1532-1541”, en Fernando I, 1503-1564. Socialización, vida privada y actividad pública de un Emperador del Renacimiento, eds. Alfredo Alvar y Friedrich Edelmayer (Madrid: Sociedad Estatal de Conmemoraciones Culturales, 2004), 358-362.

Korpás, Zoltán. “Ami a magyarországi hadjárat után történt. Bernardo de Aldana és a spanyol zsoldosok sorsa 1552 után”, Fons 3 (2005): 379-398.

Korpás, Zoltán. “Álvaro de Sande hadjárata Trencsén vármegyében - 1545”, en Redite ad Cor. Tanulmányok Sabin-Tóth Péter emlékére, eds. Lilla Krász y Teréz Oborni (Budapest: ELTE Eötvös Kiadó, 2008), 199-210.

Korpás, Zoltán. "La expedición de Álvaro de Sande a Hungría Superior, 1545”, en Palabras enlazadas. Estudios en homenaje al profesor László Scholz, eds. Zsuzsanna Bárkányi y Margit Santosné Blastik (Szeged: JATE Press, 2018), 217-229.

Kropf, Lajos. "Castaldo Erdélyben”, Hadtörténeti Közlemények 8-9 (1895-1896), 5 entregas.

Laferl, Christopher F. Die Kultur der Spanier in Österreich unter Ferdinand I. 1522-1564 (Wien: Böhlau, 1997).

Martínez de Merlo, Jesús. "La organización de los ejércitos en los Austrias", Revista de Historia Militar I extraordinario (2017): 135-186.

Martínez Ruíz, Enrique, Los soldados del Rey: los ejércitos de la Monarquía Hispánica (14801700) (Madrid: Actas, 2008). 
Oborni, Teréz. Erdély pénæü̈gyei I. Ferdinánd uralma alatt (Budapest: Fons Könyvek, 2002).

Oborni, Teréz. "From Province to Principality: Continuity and Change in Transylvania in the First Half of the Sixteenth Century", en Fight Against the Turk in CentralEurope in the First Half of the 16th Century, ed. István Zombori (Budapest: Historia Ecclesiastica Hungarica Alapítvány, 2004), 165-180.

Oborni, Teréz. "Between Vienna and Constantinople: Notes on the Legal Status of the Principality of Transylvania", en The European Tributary States of the Ottoman Empire in the Sixteenth and Seventeenth Centuries, eds. Gábor Kármán y Lovro Kunčević (Leiden-Boston: Brill, 2013), 67-89.

Oborni, Teréz. "Die Plane des Wiener Hofes zur Rückeroberung Siebenbürgens 1557-1563", en Kaiser Ferdinand I. Ein mitteleuropaischer Herrscher, eds. Martina Fuchs, Teréz Oborni y Gábor Ujváry (Münster: Aschendorff, 2005), 277-298 [=Geschichte in der Epoche Karls V. Band 5].

Oborni, Teréz. Az ördöngös Barát. Fráter György (1482-1551) (Pécs-Budapest: Kronosz, 2017).

Pálffy, Géza. "Várfeladók feletti itélkezés a 16-17. századi Magyarországon”, Levéltári Közlemények 1-2 (1997): 216-217.

Pálffy, Géza. A császárváros védelmében. A gyôri kapitányság története 1526-1598 (Győr: Gyớr-Moson-Sopron Megye Györi Levéltára, 1999).

Pálffy, Géza. The Kingdom of Hungary and the Habsburg Monarchy in the Sixteenth Century (Boulder, Colorado: Social Science Monographs-Wayne, New Jersey: Center for Hungarian Studies and Publications, Inc. - New York, Columbia University Press, 2009) =East European Monographs, DCCXXXV; CHSP Hungarian Studies Series, 18).

Pálffy, Géza y Perger, Richard. “A magyarországi török háborúk résztvevőinek síremlékei Bécsben (XVI-XVII. század.) [Wiener Grabmäler der Teilnehmer der Türkenkriegen in Ungarn (Datenbank - 16-17. Jahrhundert)]", Fons 5 (1998): 207-264.

Parker, Geoffrey. The Army of Flanders and the Spanish Road (London: Cambridge University Press, 1972).

Quatrefages, René. Los tercios (Madrid: Fundación Universitaria Española, 1983).

Recibido: 12 de diciembre de 2019

Aprobado: 28 de abril de 2020 